\title{
DAMPAK KETIDAKSTABILAN NILAI TUKAR RUPIAH TERHADAP PERMINTAAN UANG M2 DI INDONESIA
}

\author{
Etty Puji Lestari \\ Fakultas Ekonomi Universitas Terbuka, Jakarta \\ E mail: ettypl@mail.ut.ac.id
}

\begin{abstract}
This article attempts to estimate demand for M2 money in Indonesia using time series non-stationary technique in 1997.1 - 2006.4. There are four methods are used in research, first, VAR estimation used to forecast model which have interaction of data time series. Second, function impulse response to see response from every variable to structural innovation of the other variables at the same time. Third, variance decomposition to know dissociating variation change of shock from each variable to other variables in model. Fourth method, ADL ECM to see long-range adjustment in variable, before and after addition of variable. The result, there are non-stationary condition in the time series data in the research. Result of VAR estimation show that there is no causality relation two ways among fifth of variable. From impulse, response known that response of M2 variable to other variable very fluctuative but finally the condition will return to stabilize.
\end{abstract}

Keywords: instability of exchange rate, $M 2$ money, vector autoregression

\section{PENDAHULUAN}

Perekonomian Indonesia masih menunjukkan kinerja yang cukup baik sampai awal tahun 1997 yang ditandai oleh menguatnya beberapa indikator makro ekonomi. Pada tahun 1996, tingkat pertumbuhan ekonomi masih mencapai 7,8 persen per tahun dan investasi langsung luar negeri mencapai $\$ 6,5$ juta pada tahun fiskal 1996/1997. Sementara itu cadangan devisa resmi pemerintah mencapai \$20 juta pada bulan Maret 1997, serta tingkat depresiasi rupiah terhadap dolar Amerika masih terpelihara pada kisaran 3-5 persen (Bank Indonesia, 1997).

Krisis ekonomi dan keuangan yang awalnya melanda Thailand berdampak pada perekonomian negara-negara ASEAN, ter- masuk Indonesia. Perekonomian Indonesia mulai mengalami perubahan yang signifikan setelah pada pertengahan tahun 1997 muncul masalah yang menghantam perdagangan valuta asing di kawasan Asia, yang diawali dengan guncangan pasar valuta asing di Thailand dan kemudian menjalar ke pasar valuta asing negara-negara lain termasuk Indonesia. Pada akhir periode tahun 1997, depresiasi riil nilai tukar rupiah terhadap dolar AS mencapai angka 68,7 persen. Pada saat keseimbangan eksternal tergangggu, terjadi pula ketidakseimbangan internal. Kenaikan harga barang-barang secara otomatis akan memperbesar angka inflasi. Pada akhir tahun 1997 angka inflasi mencapai 11,1 persen per tahun dan terus meningkat hingga 


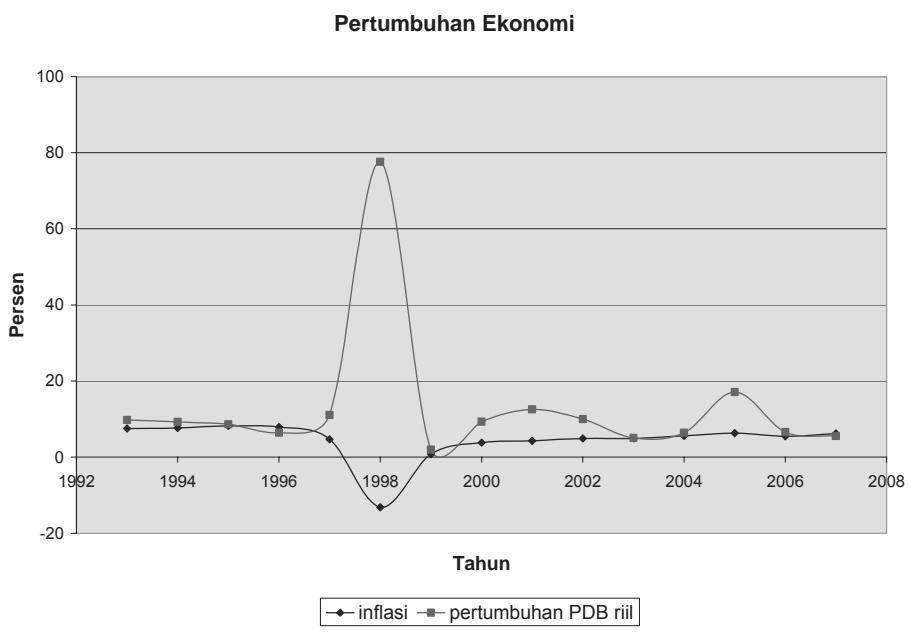

Gambar 1. Laju Inflasi dan Pertumbuhan PDB Riil

mencapai 168,32 persen per tahun pada tahun berikutnya (Bank Indonesia, 1999).

Pada kasus Indonesia, krisis nilai tukar mata uang Rupiah terhadap dolar, terus menular ke sektor-sektor lainnya hingga menimbulkan krisis ekonomi. Pada akhir tahun 1997, pertumbuhan ekonomi tahunan (PDB riil) tercatat sebesar 4,7 persen sedang pada akhir tahun 1998 turun sebesar -13,2 persen (Gambar 1). Sebelum terjadinya krisis ekonomi, antara tahun 1990 sampai 1996, pertumbuhan ekonomi Indonesia rata-rata mencapai 8 persen. Setelah terjadinya krisis ekonomi tahun 1997 maka pertumbuhan ekonomi Indonesia antara tahun 2000 sampai 2006 menurun dengan rata-rata 4,86 persen.

Perekonomian Indonesia mulai dikatakan membaik pada tahun 2000 yang dibuktikan dengan adanya penurunan inflasi dari 77,63 persen pada tahun 1998 menjadi 2,01 pada tahun 2000, namun kembali meningkat pada tahun 2002 sebanyak 12,55 persen. Membaiknya kinerja ini juga diikuti oleh meningkatnya pendapatan perkapita masya- rakat (percapita gross national product) yaitu dari 4.49 juta rupiah pada tahun 1998 dan 5,78 juta rupiah (2000) menjadi 6,86 juta rupiah pada tahun 2001 (BPS, 2003). Pemulihan kondisi tersebut ditunjang oleh membaiknya infrastuktur yang ada serta kebijakan-kebijakan yang diterapkan oleh pemerintah baik fiskal maupun moneter.

Kondisi non stasioner tersebut menunjukkan bahwa secara teoritis terdapat masalah yang berkaitan dengan stabilitas. Stabilitas merupakan syarat utama dari stasioneritas data, terutama data time series. Kondisi non stasioner terjadi jika nilai rata-rata (mean), variance dan covariance tidak konsisten sepanjang waktu. Stabilisasi pada data time series berhubungan erat dengan stabilitas ekonomi makro. Jika ada permasalahan yang berhubungan dengan variabel non stasioner maka hasil estimasi akan mengalami regresi lancung (spurious regression atau spurious correlation problem). Sejauh ini perdebatan akademik menyangkut kelancungan pertama kali dikemukakan oleh Granger dan Newbold pada tahun 1974 dan tahun 1977 serta dikaji 
lebih lanjut oleh Phillips pada tahun 1986. Dampak yang ditimbulkan oleh regresi lancung antara lain: koefisien penaksir tidak efisien, peramalan berdasarkan regresi tersebut akan meleset dan uji baku umum menjadi tidak sahih (Insukindro, 1991).

Untuk mencapai stabilisasi ekonomi maka diperlukan target-antara di antaranya jumlah uang beredar. Di sisi lain pengendalian jumlah uang beredar (JUB) sulit diukur. Pengendalian JUB berkaitan erat dengan perilaku permintaan uang masyarakat terutama untuk jangka panjang. Salah satu variabel penentu yang cukup berarti dalam dalam teori ekonomi adalah kurs atau nilai tukar yang sifatnya fluktuatif. Variabel ini menjadi lebih dominan pada masa krisis. Perekonomian suatu negara dikatakan bebas dari krisis apabila mampu mencapai nilai kurs yang stabil.

Berangkat dari kondisi yang sangat fluktuatif tersebut, maka artikel ini ingin menganalisis permintaan uang di Indonesia dengan teknik time series non stasioner pada saat terjadi ketidakstabilan nilai tukar pada tahun 1997.1-2006.4; menganalisis perilaku variabel penentu permintaan uang yang memiliki karakteristik yang sangat fluktuatif di Indonesia terutama setelah Bank Indonesia mengenakan sistem kurs mengambang bebas; dan mengukur besarnya kecepatan penyesuaian (speed of adjustment) jangka panjang permintaan uang.

\section{METODE PENELITIAN}

\section{Model Estimasi Permintaan Uang}

Penggunaan model perekonomian terbuka dapat diterima untuk kasus permintaan uang di Indonesia, mengingat bahwa transaksi terhadap luar negeri bebas dilakukan oleh masyarakat Indonesia. Masyarakat telah dibebaskan untuk memegang valuta asing dengan sistem kurs mengambang terkendali (managed floating exchange rate) sejak awal tahun 1980-an dan sekarang sistem kurs mengambang penuh (free floating exchange rate). Kebijakan ini memungkinkan masyarakat di dalam negeri untuk merelokasikan kekayaannya dengan memasukkan mata uang asing sebagai salah satu bentuk kekayaan yang dipegang sehingga memungkinkan maksimisasi return dari asset yang mereka pegang.

Perdebatan pemilihan variabel kunci dalam menjelaskan perilaku permintaan uang tidak terlalu banyak variasinya. Penelitian yang dilakukan oleh Hendry dan Erricson (1991) dan Mizao (1997) menggunakan 4 variabel yaitu $\mathrm{M}, \pi$, Y dan R yang masingmasing menunjukkan $\mathrm{M}_{1}$ riil, tingkat laju inflasi, output riil, dan tingkat bunga berjangka. Selanjutnya melihat kondisi keterbukaan yang dialami Indonesia sejak awal tahun 1980-an maka berbeda dengan penelitian Morimune dan Zhao (1997), model dapat diperluas untuk memasukkan variabel nilai tukar dan permintaan uangnya dipilih $\mathrm{M}_{2}$ karena memiliki skala yang lebih luas dibandingkan $\mathrm{M}_{1}$. Model penelitian ini dapat dituliskan sebagai berikut:

$M_{d}=f\left(Y_{t}, E R_{t}, r_{t}, \operatorname{Inf}_{t}\right)$

dimana

$\mathrm{M}_{\mathrm{d}}$ adalah permintaan uang $\mathrm{M}_{2}$

$\mathrm{Y}_{\mathrm{t}}$ adalah output atau pendapatan nasional riil $\mathrm{ER}_{\mathrm{t}}$ adalah nilai tukar rupiah terhadap dolar $r_{t}$ adalah tingkat suku bunga pasar dan $\mathrm{Inf}_{\mathrm{t}}$ adalah tingkat inflasi. 
Penelitian ini menggunakan data sekunder yang diperoleh dari Badan Pusat Statistik, Statistik dan Keuangan Indonesia, Bank Indonesia, International Financial Statistic (IFS), World Bank dan beberapa sumber literatur lainnya. Rentang waktu yang digunakan dalam penelitian adalah mulai tahun 1997.1 sampai 2006.4 .

Penelitian ini menggunakan 4 (empat) metode estimasi, yaitu pertama, Vector Autoregression/VAR untuk melihat estimasi hubungan dalam jangka panjang. Metode VAR diyakini mampu melakukan peramalan yang lebih baik dibandingkan model persamaan struktural. Metode kedua adalah melakukan pengujian terhadap impulse response function untuk melihat respon dari setiap variabel terhadap struktural inovasi variabel lainnya dalam model pada periode waktu bersamaan. Metode ketiga adalah menguji variance decomposition yang berguna untuk memisahkan variasi perubahan shock dari setiap variabel terhadap variabel lain dalam model. Metode terakhir yang dipakai adalah melakukan estimasi model ADL ECM. Metode estimasi ini merupakan turunan dari model VAR atau metode estimasi VAR yang memasukkan variabel tambahan (ECT) ke dalam analisis. Tujuannya adalah untuk melihat penyesuaian jangka panjang dalam variabel yang diamati sebelum dan sesudah penambahan variabel.

\section{Uji Akar Unit Autoregressive}

Tujuan uji akar unit adalah untuk mengetahui ada tidaknya akar unit (komponen random walk). Uji akar unit yang digunakan dalam penelitian ini adalah dua uji yang dikembangkan oleh Dickey dan Fuller (1981). Uji akar unit dapat dipandang sebagai uji stasio- neritas karena pada prinsipnya uji tersebut dimaksudkan untuk mengamati apakah koefisien tertentu dari model otoregressif yang ditaksir memiliki nilai satu atau tidak. Namun demikian model otoregresif memiliki distribusi yang tidak baku seperti uji t dan uji f yang tidak cukup layak digunakan untuk menguji hipotesa. Uji tersebut dikembangkan dengan penaksiran otoregresif sebagai berikut:

$\mathrm{X}_{\mathrm{t}}=\alpha+\theta \mathrm{X}_{\mathrm{t}-1}+\mathrm{u}_{\mathrm{t}}$

dimana parameter $\theta$ untuk data time series diasumsikan positip. Xt menjadi non stasioner jika parameter $\theta$ sama dengan atau lebih dari satu. Time series persamaan 1 stasioner jika $\theta<1$. Proses pengujiannya dilakukan dengan mengaplikasikan OLS ke dalam persamaan 1 sehingga kita mendapatkan $\hat{\theta}$ nilai estimasi dari $\theta$. Selanjutnya dilakukan uji $\mathrm{t}$ (t-test) pada hipotesis nol Ho: $\theta=1$ melawan Ha: $\theta<1$. Jika $\hat{\theta}$ merupakan standar error estimasi dari $\hat{\theta}$ maka uji statistik (t-statistik/ TS) dirumuskan sebagai berikut:

$\mathrm{TS}=\frac{\hat{\theta}-1}{\mathrm{~S}_{\hat{\theta}}}$

penolakan Ho berimplikasi pada data yang stasioner.

Kajian yang dilakukan oleh D.A Dickey dan W.F Fuller (1981) dilakukan dengan menulis persamaan 1 menjadi:

$$
\begin{aligned}
& \Delta \mathrm{X}_{\mathrm{t}}=\alpha+\theta * \mathrm{X}_{\mathrm{t}-1}+\mathrm{u}_{\mathrm{t}}, \\
& \theta^{*}=\theta-1
\end{aligned}
$$


dengan pengujian Ho: $\theta=1$ melawan Ha: $\theta<$ 1 dalam persamaan 1 sama dengan pengujian Ho: $\theta *=0$ melawan Ha: $\theta *<0$ pada persamaan 3. Pengujian yang terakhir terakhir sering disebut uji akar unit (unit root test). Dickey-Fuller telah mengembangkan sebuah simulasi dengan menabulasi distribusi t-rasio sampel besar dengan menguji hipotesa nol (Ho) yaitu $\theta *=0$. Mereka menemukan adanya bias ke bawah (downward biased) distribusi t rasio pada nol seperti jika estimator OLS $\hat{\theta} *$ yang tidak bias tetapi pada nilai yang kurang dari nol (lihat Thomas, 1997:406 dan 412, Greene, 2000: 750).

Pada situasi seperti ini dihasilkan t-rasio dengan simbol $\mathrm{t}_{1} * \mathrm{t}_{1} *$ yang disebut sebagai statistic DF (Dickey Fuller statistic). Beberapa nilai kritis Dickey Fuller untuk t 1 * ditunjukkan pada Tabel 1.

Penelitian ini menggunakan uji akar-akar unit yang dikembangkan oleh Dickey \& Fuller (1981, hal 1057-1072). Tima series yang memiliki akar unit biasa disebut sebagai random walk time series (Gujarati, 728). Uji ini dilakukan dengan dua cara, yaitu dengan memasukkan konstanta tetapi tidak memasukkan trend dan dengan memasukkan konstanta dan trend.

\section{Estimasi Jangka Panjang dengan Var}

Analisis kointegrasi sering digunakan sebagai salah satu metode dalam menentukan bentuk hubungan jangka panjang. Metode lainnya adalah Vector Autoregression (VAR) yang diperkenalkan oleh Sims (1980). Metode ini didasarkan atas reaksi terhadap pendekatan ekonometri tradisional untuk menangani model simultan (multi-equation simultaneous models). Kunci penting dari metode ini adalah pembagian variabelvariabel menjadi variabel endogen ke dalam model dan variabel yang diperlakukan sebagai variabel eksogen (Litterman, 1985).

VAR sering digunakan untuk meramalkan model yang memiliki data time series yang saling berhubungan (interrelated time series) dan digunakan untuk menganalisis dampak dari variabel pengganggu (random disturbances) yang dinamis. Kriteria pengujian secara statistik dilakukan dengan uji parsial (uji-t) dan uji goodness of fit; $\mathrm{t}_{\text {tabel }}(2$ tail, $\alpha=0.05, \infty)=1.960$. Uji goodness of fit dilakukan dengan melihat koefisien determinasinya $\left(\mathrm{R}^{2}\right)$. Uji ini bertujuan untuk mengukur seberapa besar variasi dari variabelvariabel independen dapat menjelaskan variabel dependen.

Model VAR yang digunakan dalam penelitian ini sebagai berikut:

$$
\mathrm{Y}_{\mathrm{t}}=\Gamma \mathrm{Y}_{\mathrm{t}-1}+\varepsilon_{\mathrm{t}}
$$

dimana vektor $\mathrm{Yt}=\left|\mathrm{Y}_{\mathrm{t}}, \mathrm{Z}_{\mathrm{t}}\right|$. Lakukan turunan pertama (first difference) menjadi:

Tabel 1. Nilai Kritis untuk $t_{1}{ }^{*}$

\begin{tabular}{|c|c|c|c|c|c|c|}
\hline \multirow{2}{*}{ Nilai kritis dari $\mathrm{t}_{1}{ }^{*}$} & \multicolumn{5}{|c|}{ Jumlah sample $n$} & \multirow{2}{*}{$\begin{array}{l}\text { Nilai t biasa } \\
\qquad(n=\infty)\end{array}$} \\
\hline & 25 & 50 & 100 & 500 & $\infty$ & \\
\hline Tingkat sig 0,01 & -3.75 & -3.58 & -3.51 & -3.44 & -3.43 & -2.33 \\
\hline Tingkat sig 0,05 & -3.00 & -2.93 & -2.89 & -2.87 & -2.86 & -1.65 \\
\hline Tingkat sig. 0,10 & -2.63 & -2.60 & -2.58 & -2.57 & -2.57 & -1.28 \\
\hline
\end{tabular}




$$
\begin{aligned}
& \mathrm{y}_{\mathrm{t}}-\mathrm{y}_{\mathrm{t}-1}=(\Gamma-1) \mathrm{y}_{\mathrm{t}-1}+\varepsilon_{\mathrm{t}} \mathrm{t} \text { dan } \\
& \Delta \mathrm{yt}=\Pi \mathrm{y}_{\mathrm{t}-1}+\varepsilon_{\mathrm{t}}
\end{aligned}
$$

Jika semua variabel terintegrasi I(1), maka semua variabel $\mathrm{M}$ pada sisi kiri adalah $\mathrm{I}(0)$. Matrik $\Pi$ menghasilkan kombinasi linier dari variabel dalam $\mathrm{Y}_{\mathrm{t}}$. namun tidak semua kombinasi linier terkointegrasi meskipun model representasi VAR dipastikan ada. Jika model ini diasumsikan sebagai unrestricted VAR maka hasil matriks koefisien harus diperingkat. Implikasinya, jika variabel benar-benar terkointegrasi maka koefisien matriksnya tidak akan kehilangan kesesuaiannya (goodnes of fit) (Greene, 2000:794).

Menurut Morimune dan Zhao (1997), jika Xt menjadi kolom vektor dari sejumlah $\mathrm{p}$ komponen dengan I(1), maka sistem yang dapat ditulis dalam jumlah order VAR yang terbatas (restricted VAR) seperti berikut:

$$
\Delta \mathrm{X}_{\mathrm{t}}=\mu+\Pi \mathrm{x}_{\mathrm{t}-1}+\ldots+\mathrm{Tk} \Delta \mathrm{x}_{\mathrm{t}-\mathrm{k}}+\varepsilon_{\mathrm{t}}
$$

dimana $\mathrm{t}=1,2,3 \ldots \mathrm{t}$ dan $\varepsilon_{\mathrm{t}}$ independen, $\mathrm{E}\left(\varepsilon_{\mathrm{t}}\right)=0$ dan covariance $\left(\varepsilon_{\mathrm{t}}\right)=\sum$. Model koreksi kesalahan (ECM) terjadi ketika matrik $\Pi$ dibatasi. Hanya variabel $\Pi x_{t}$ yang menunjukkan masih ada hubungan jangka panjang dimana masing-masing variabel tidak berubah nilainya. Dalam jangka pendek variabel $\Pi \mathrm{x}_{\mathrm{t}}$ tidak cocok dengan keseimbangan masa lalu dan sisi kiri adalah penyesuaian dari ketidakcocokannya (Gujarati, 1995).

\section{Impulse Response Function dari Model Var}

Impulse Response Function menggambarkan respon dari setiap variabel terhadap struktural inovasi variabel lainnya dalam model pada periode waktu bersamaan. Estimasi impulse response dapat dilihat pada saat ini dan akan datang. Selanjutnya model VAR dapat ditulis sebagai suatu vektor rata-rata bergerak atau VMA (vector moving average). Jika dituliskan dalam bentuk matriks aljabar dari bentuk standar VAR maka akan didapat persamaan berikut:

$$
\left[\begin{array}{l}
y_{t} \\
z_{t}
\end{array}\right]=\left[\begin{array}{l}
\bar{y} \\
\bar{z}
\end{array}\right]+\sum_{i=0}^{\infty}\left[\begin{array}{ll}
a_{11} & a_{12} \\
a_{22} & a_{22}
\end{array}\right]\left[\begin{array}{l}
e_{1 t-i} \\
e_{2 t-i}
\end{array}\right]
$$

dimana $\left\{\mathrm{y}_{\mathrm{t}}\right\}$ dan $\left\{\mathrm{z}_{\mathrm{t}}\right\}$ mempunyai hubungan dengan $\left\{\mathrm{e}_{1 \mathrm{t}}\right\}$ dan $\left\{\mathrm{e}_{2 \mathrm{t}}\right\}$ secara berurutan. Dengan menggunakan $\left\{\varepsilon_{\mathrm{yt}}\right\}$ dan $\left\{\varepsilon_{\mathrm{zt}}\right\}$, selanjutnya dengan menggunakan operasi matriks aljabar maka vector error dapat ditentukan menjadi:

$\left[\begin{array}{l}e_{1 t} \\ e_{2 t}\end{array}\right]=\left[1 /\left(1-b_{12} b_{21}\right)\right]\left[\begin{array}{cc}1 & -b_{12} \\ -b_{21} & 1\end{array}\right]\left[\begin{array}{l}\varepsilon_{y t} \\ \varepsilon_{z t}\end{array}\right]$

Moving average representation dalam persamaan (4) dan (5) dapat ditulis dengan kaitan $\left\{\varepsilon_{\mathrm{yt}}\right\}$ dan $\left\{\varepsilon_{\mathrm{zt}}\right\}$ secara berulang menjadi:

$$
\left[\begin{array}{c}
y_{t} \\
z_{t}
\end{array}\right]=\left[\begin{array}{c}
\bar{y} \\
\bar{z}
\end{array}\right]+\sum_{i=0}^{\infty}\left[\begin{array}{ll}
\Phi_{11}(i) & \Phi_{12}(i) \\
\Phi_{21}(i) & \Phi_{22}(i)
\end{array}\right]\left[\begin{array}{c}
\varepsilon_{y t-i} \\
\varepsilon_{z t-1}
\end{array}\right]
$$

Empat satuan koefisien $\Phi_{11}(\mathrm{i}), \Phi_{12}(\mathrm{i}), \Phi_{21}(\mathrm{i})$, dan $\Phi_{22}(\mathrm{i})$ inilah yang disebut dengan impulse response function (IRF). 
dimana:

$$
\begin{aligned}
\Phi_{\mathrm{ij}}(i)= & \text { efek dari struktural shock pada } \mathrm{y} \\
& \text { dan } \mathrm{z} \\
\Phi_{\mathrm{ij}}(0)= & \text { impact multipliers } \\
\Sigma \Phi_{\mathrm{ij}}(i)= & \text { cumulative multipliers } \\
\Sigma \Phi_{i j}(i)= & \text { pada saat } \mathrm{n} \rightarrow \infty=\text { long run } \\
& \text { multipliers }
\end{aligned}
$$

\section{Variance Decomposition dari $\mathbf{M}_{2}$}

Variance decomposition memisahkan variasi perubahan shock dari setiap variabel terhadap variabel lain dalam model. Setiap variabel perubahan dalam model diasumsikan tidak berkorelasi. Variance decomposition menggambarkan besarnya sumbangan pengaruh dari suatu variabel perubahan terhadap variabel lain dalam model. Bentuk VMA dari variabel x pada satu periode di depan dituliskan sebagai berikut:

$$
\mathrm{X}_{\mathrm{t}+1}=\mathrm{X}+\sum_{\mathrm{i}=1}^{\infty} \varphi_{\mathrm{i}} \varepsilon_{\mathrm{t}+1-\mathrm{i}}
$$

Forecast error pada satu periode ke depan adalah:

$$
\mathrm{E}_{\mathrm{t}} \mathrm{X}_{\mathrm{t}+1}=\mathrm{X}+\sum_{\mathrm{i}=1}^{\infty} \varphi_{\mathrm{i}} \varepsilon_{\mathrm{t}+1-\mathrm{i}}
$$

Peramalan satu periode kedepan dilambangkan dengan $\varphi_{0} \varepsilon_{t+1}$. Forecast error pada periode $\mathrm{n}$ ke depan adalah:

$$
X_{t+n}-E_{t} X_{t+1}=X+\sum_{i=1}^{\infty} \varphi_{i} \varepsilon_{t+1-i}
$$

Forecast error pada $\mathrm{n}$ periode ke depan untuk variabel y adalah:

$$
\begin{aligned}
\mathrm{Y}_{\mathrm{t}+\mathrm{n}}-\mathrm{e}_{\mathrm{t}} \mathrm{y}_{\mathrm{t}+\mathrm{n}}= & \varphi_{11}(0) \varepsilon_{\mathrm{yt}+\mathrm{n}}+\varphi_{11}(1) \varepsilon_{\mathrm{yt}+\mathrm{n}-1}+ \\
& \ldots+\varphi_{11}(\mathrm{n}-1) \varepsilon_{\mathrm{yt}+1} \\
& \varphi_{12}(0) \varepsilon_{\mathrm{zt}+\mathrm{n}}+\varphi_{12}(1) \varepsilon_{\mathrm{zt}+\mathrm{n}-1}+ \\
& \ldots+\varphi_{12}(\mathrm{n}-1) \varepsilon_{\mathrm{zt}+1}
\end{aligned}
$$

Variance dari forecast error $\mathrm{Y}_{\mathrm{t}+\mathrm{n}}$ periode $\mathrm{n}$ ke depan adalah $\sigma_{\mathrm{y}}(\mathrm{n})^{2}$, dimana:

$$
\begin{aligned}
\sigma_{\mathrm{y}}(\mathrm{n})^{2}= & \sigma_{\mathrm{y}}^{2}\left[\varphi_{11}(0)^{2}+\varphi_{11}(1)^{2}+\ldots+\varphi_{11}(\mathrm{n}-1)^{2}\right] \\
& +\sigma_{\mathrm{z}}^{2}\left[\varphi_{12}(0)^{2}+\varphi_{12}(1)^{2}+\ldots\right. \\
& \left.+\varphi_{12}(\mathrm{n}-1)^{2}\right]
\end{aligned}
$$

forecast error variance decomposition adalah proporsi dari $\sigma_{\mathrm{y}}(\mathrm{n})^{2}$ terhadap shock y dan shock z. Sehingga forecast error variance decomposition pada shock y adalah:

$\sigma_{y}^{2}\left[\varphi_{11}(0)^{2}+\varphi_{11}(1)^{2}+\ldots+\varphi_{11}(n-1)^{2}\right] / \sigma_{y}(n)^{2}$

Sedangkan forecast error variance decomposition pada shock $\mathrm{z}$ adalah:

$$
\sigma_{z}^{2}\left[\varphi_{11}(0)^{2}+\varphi_{11}(1)^{2}+\ldots+\varphi_{11}(n-1)^{2}\right] / \sigma_{y}(n)^{2}
$$

\section{Estimasi Model ADL ECM}

Penelitian ini menggunakan model ADL ECM (Autoregressive Distributed Lag Error Correction Models) untuk mengestimasi fungsi permintaan uang seperti yang dipakai oleh Hendry et al, yaitu:

$$
Y_{t}=\alpha_{0}+\alpha_{1} Y_{t-1}+\beta_{0} X_{t}+\beta_{1} X_{t-1}+\xi_{t}
$$

persamaan ini kemudian ditransformasikan kedalam bentuk ECM menjadi 


$$
\begin{aligned}
\Delta \mathrm{Y}_{\mathrm{t}}= & \alpha_{0}+\alpha^{*}{ }_{1}\left(\mathrm{Y}_{\mathrm{t}-1}-\beta \mathrm{X}_{\mathrm{t}-1}\right)+ \\
& \beta_{0} \Delta \mathrm{X}_{\mathrm{t}}+\xi_{\mathrm{t}}
\end{aligned}
$$

Bentuk ECM ini berbeda dengan bentuk VAR turunan atau VAR yang memasukkan $\mathrm{X}_{\mathrm{t}}$ atau $\Delta \mathrm{X}_{\mathrm{t}}$ yang disetarakan dengan variabel dependen. Secara umum model ADL dituliskan sebagai berikut:

$$
\mathrm{Y}_{\mathrm{t}}=\alpha_{0}+\sum_{\mathrm{i}=1}^{\mathrm{m}} \alpha_{\mathrm{i}} \mathrm{Y}_{\mathrm{t}-1}+\sum_{\mathrm{i}=1}^{\mathrm{p}} \sum_{\mathrm{i}=0}^{\mathrm{n}} \beta \mathrm{jiXj} \mathrm{j}_{\mathrm{t}-\mathrm{i}}+\xi \mathrm{t}_{\mathrm{t}}
$$

dimana $\mathrm{p}$ merupakan indeks variabel penjelas yang masing-masing memiliki distribusi kelambanan. Model ADL dapat ditransformasikan dalam bentuk ECM namun disetarakan dengan termin tambahan (extra term) $\Delta \mathrm{X}_{\mathrm{jt}, \mathrm{j}} \mathrm{j}=1, . \mathrm{p}$ yang sangat berguna dalam studi empiris. Tetapi termin tambahan $\Delta \mathrm{X}_{\mathrm{jt}}$ membuat estimasi menjadi bermasalah ketika dapat berkorelasi dengan error term dari regresi. Model ADL secara konsisten dapat diestimasi dengan teknik variabel tambahan.

\section{HASIL PENELITIAN DAN PEMBAHASAN}

Berdasar hasil estimasi, diketahui bahwa nilai t-statistik atau nilai hitung ADF untuk variabel $\mathrm{M}_{2}$, pendapatan nasional, dan suku bunga sudah stasioner pada derajat kepercayaan satu persen, sedangkan variabel inflasi stasioner pada derajat kepercayaan lima persen. Dalam uji ini hanya variabel kurs yang tidak lolos uji akar unit sehingga harus diteruskan dengan uji derajat integrasi satu. Hal ini menunjukkan ada masalah dengan akar unit yang menggambarkan situasi non stasioner. Untuk selanjutnya perlu dilakukan uji derajat integrasi untuk mengetahui pada derajat ke berapa data-data tersebut stasioner. Hasil selengkapnya uji akar unit dapat dilihat

\begin{tabular}{|c|c|c|c|c|}
\hline \multirow{2}{*}{ VARIABEL } & \multirow{2}{*}{ UJI AKAR UNIT } & \multirow{2}{*}{ DERAJAT INTEGRASI 1} & \multicolumn{2}{|c|}{ NILAI KRITIS ADF } \\
\hline & & & Derajat kepercayaan (\%) & t statistik \\
\hline \multirow[t]{2}{*}{$\mathrm{M}_{2}$} & 2.707622 & & 1 & -2.627238 \\
\hline & (lolos) & & $\begin{array}{c}5 \\
10\end{array}$ & $\begin{array}{l}-1.949856 \\
-1.611469\end{array}$ \\
\hline \multirow[t]{2}{*}{ Y } & 3.572500 & & 1 & -2.628961 \\
\hline & (lolos) & & $\begin{array}{c}5 \\
10\end{array}$ & $\begin{array}{l}-1.950117 \\
-1.611339\end{array}$ \\
\hline \multirow[t]{2}{*}{ ER } & 0.673967 & 1.708373 & 1 & -2.627238 \\
\hline & (tidak lolos) & (lolos) & $\begin{array}{c}5 \\
10\end{array}$ & $\begin{array}{l}-1.949856 \\
-1.611469\end{array}$ \\
\hline \multirow[t]{2}{*}{ INF } & -2.073001 & & 1 & -2.625606 \\
\hline & (lolos) & & $\begin{array}{c}5 \\
10\end{array}$ & $\begin{array}{l}-1.949609 \\
-1.611593\end{array}$ \\
\hline \multirow[t]{2}{*}{$\mathrm{R}$} & -3.154925 & & 1 & -2.641672 \\
\hline & (lolos) & & $\begin{array}{c}5 \\
10\end{array}$ & $\begin{array}{l}-1.952066 \\
-1.610400\end{array}$ \\
\hline
\end{tabular}
pada Tabel 2.

Tabel 2. Uji Akar Unit dan Uji Derajat Integrasi I 
Dari hasil perhitungan secara keseluruhan disimpulkan bahwa pengujian ini tidak perlu diteruskan ke uji kointegrasi. Namun demikian menurut Wickens \& Brusch (1988), ECM standar dari model yang dikembangkan oleh Domowitz dan El Badawi (1987) sudah sahih dan dapat digunakan untuk melakukan inferensi.

\section{Penentuan Lag Optimal Model Var}

Untuk dapat melakukan estimasi model VAR maka perlu ditentukan seberapa banyak variabel lag length dibutuhkan dalam model. Di dalam model autoregresi dimana peran waktu sangat berpengaruh maka peranan lag didalam model menjadi sangat penting. Penentuan lag length juga bertujuan untuk mendapatkan model yang tepat untuk diestimasi, dimana model tersebut ditentukan oleh banyaknya jumlah lag yang digunakan.

Beberapa rumus yang biasa dipakai untuk menentukan lag optimal disajikan dalam Tabel 3.
Tabel 3. Penentuan Lag Optimal

\begin{tabular}{lc}
\hline \multicolumn{1}{c}{ Kriteria } & \multicolumn{1}{c}{ Rumus } \\
\hline $\begin{array}{l}\text { Final Prediction } \\
\text { Error (FPE) }\end{array}$ & {$\left[\frac{R S S}{T}\right] X \frac{T+k}{T-k}$} \\
$\begin{array}{l}\text { Akaike Information } \\
\text { Criterion (AIC) }\end{array}$ & {$\left[\frac{R S S}{T}\right] X e^{(2 k / T)}$} \\
$\begin{array}{l}\text { Schwarz } \\
\text { Information } \\
\text { Criterion (SIC) } \\
\text { Hannan-Quinn } \\
\text { Information } \\
\text { Criterion (HQ) }\end{array}$ & {$\left[\frac{R S S}{T}\right] X T^{k j / T}$} \\
\hline
\end{tabular}

Hasil dari uji kelambanan optimal VAR nampak dalam Tabel 4. Tanda (*) bintang menunjukkan rekomendasi kelambanan (lag) dari masing-masing kriteria statistik yang dipakai. Dari hasil perhitungan diperoleh hasil bahwa empat dari lima kriteria pengujian kelambanan optimal di atas (LR, FPE, AIC, dan HQ) menunjukkan lag optimal sebesar tiga kuartal dan hanya satu dari kriteria yaitu SC yang menyarankan dua kuartal. Dengan hasil ini maka kelambanan

\section{Tabel 4. Hasil Uji Kelambanan Optimal Var}

VAR Lag Order Selection Criteria

Endogenous variables: M2 INF R XR Y

Exogenous variables: $\mathrm{C}$

Date: 11/23/07 Time: 10:12

Sample: 1997:1 2006:4

Included observations: 33

\begin{tabular}{cccccc}
\hline Lag & LogL & LR & FPE & AIC & SC \\
\hline 0 & 256.0274 & NA & $1.70 \mathrm{E}-13$ & -15.21378 & -14.98704 \\
1 & 403.8607 & 241.9091 & $1.01 \mathrm{E}-16$ & -22.65823 & -21.29776 \\
2 & 468.0934 & 85.64361 & $1.05 \mathrm{E}-17$ & -25.03597 & $-22.54179^{*}$ \\
3 & 510.4817 & $43.67280^{*}$ & $5.01 \mathrm{E}-18^{*}$ & $-26.08980^{*}$ & -22.46191 \\
\hline
\end{tabular}

* indicates lag order selected by the criterion

LR: sequential modified LR test statistic (each test at $5 \%$ level)

FPE: Final prediction error

AIC: Akaike information criterion

SC: Schwarz information criterion

$H Q$ : Hannan-Quinn information criterion 
(lag) optimal yang disarankan dipakai dalam model VAR adalah sebesar 3 kuartal.

\section{Hasil Estimasi Var}

Setelah dilakukan uji akar unit, uji derajat integrasi dan uji kelambanan optimal, berikutnya dilakukan estimasi dengan metode VAR untuk melihat estimasi jangka panjangnya. Hasil estimasi model VAR selengkapnya disajikan pada Tabel 5. Keseluruhan variabel memiliki nilai koefisien determinasi di atas 84 persen, artinya sebanyak lebih dari 84 persen variasi variabel independen mampu menjelaskan variabel dependennya.

Pengujian parsial dengan uji-t diketahui memiliki 3 (tiga) hubungan antarvariabel yang lolos uji-t, yaitu $\mathrm{M} 2(-1) \rightarrow \mathrm{M} 2, \mathrm{Inf} \rightarrow \mathrm{Y}(-$ 1), $\operatorname{Inf} \rightarrow \mathrm{Y}(-2), \operatorname{Inf} \rightarrow \mathrm{Y}(-3), \mathrm{R} \rightarrow \mathrm{R}(-3), \mathrm{R} \rightarrow$ $\mathrm{Y}(-3), \mathrm{XR} \rightarrow \mathrm{R}(-3), \mathrm{Y} \rightarrow \mathrm{Y}(-2), \mathrm{Y} \rightarrow \mathrm{Y}(-3)$, $\mathrm{Y} \rightarrow \mathrm{R}(-1), \mathrm{Y} \rightarrow(\mathrm{R}-3), \mathrm{Y} \rightarrow \mathrm{Y}(-3)$. Dari hasil

Tabel 5. Hasil Perhitungan VAR

Vector Autoregression Estimates

Date: 11/23/07 Time: 10:18

Sample(adjusted): 1998:4 2006:4

Included observations: 33 after adjusting endpoints

Standard errors in ( ) \& t-statistics in [ ]

\begin{tabular}{|c|c|c|c|c|c|}
\hline & M2 & INF & $\mathbf{R}$ & XR & $Y$ \\
\hline M2(-1) & $\begin{array}{c}0.783374 \\
(0.37096) \\
{[2.11176]}\end{array}$ & $\begin{array}{r}1.844524 \\
(1.29575) \\
{[1.42351]}\end{array}$ & $\begin{array}{r}0.251858 \\
(0.27842) \\
{[0.90460]}\end{array}$ & $\begin{array}{c}-0.468354 \\
(0.69119) \\
{[-0.67761]}\end{array}$ & $\begin{array}{r}0.044517 \\
(0.37265) \\
{[0.11946]}\end{array}$ \\
\hline M2(-2) & $\begin{array}{r}0.101779 \\
(0.45664) \\
{[0.22288]}\end{array}$ & $\begin{array}{r}-2.377601 \\
(1.59505) \\
{[-1.49061]}\end{array}$ & $\begin{array}{r}-0.153366 \\
(0.34273) \\
{[-0.44748]}\end{array}$ & $\begin{array}{r}1.043349 \\
(0.85084) \\
{[1.22626]}\end{array}$ & $\begin{array}{r}0.678514 \\
(0.45873) \\
{[1.47913]}\end{array}$ \\
\hline M2(-3) & $\begin{array}{r}-0.105720 \\
(0.32894) \\
{[-0.32140]}\end{array}$ & $\begin{array}{r}-1.172032 \\
(1.14898) \\
{[-1.02006]}\end{array}$ & $\begin{array}{r}-0.384822 \\
(0.24688) \\
{[-1.55873]}\end{array}$ & $\begin{array}{r}-0.423674 \\
(0.61289) \\
{[-0.69127]}\end{array}$ & $\begin{array}{r}0.555252 \\
(0.33044) \\
{[1.68035]}\end{array}$ \\
\hline $\operatorname{INF}(-1)$ & $\begin{array}{r}0.016692 \\
(0.05924) \\
{[0.28175]}\end{array}$ & $\begin{array}{r}0.597428 \\
(0.20694) \\
{[2.88695]}\end{array}$ & $\begin{array}{r}0.044956 \\
(0.04447) \\
{[1.01104]}\end{array}$ & $\begin{array}{r}-0.057750 \\
(0.11039) \\
{[-0.52316]}\end{array}$ & $\begin{array}{r}0.016844 \\
(0.05951) \\
{[0.28302]}\end{array}$ \\
\hline $\operatorname{INF}(-2)$ & $\begin{array}{r}-0.011220 \\
(0.06488) \\
{[-0.17294]}\end{array}$ & $\begin{array}{r}-0.438280 \\
(0.22663) \\
{[-1.93391]}\end{array}$ & $\begin{array}{r}0.007151 \\
(0.04870) \\
{[0.14686]}\end{array}$ & $\begin{array}{r}0.005899 \\
(0.12089) \\
{[0.04880]}\end{array}$ & $\begin{array}{r}-0.028079 \\
(0.06518) \\
{[-0.43082]}\end{array}$ \\
\hline $\operatorname{INF}(-3)$ & $\begin{array}{r}0.026202 \\
(0.04825) \\
{[0.54307]}\end{array}$ & $\begin{array}{r}0.155418 \\
(0.16853) \\
{[0.92221]}\end{array}$ & $\begin{array}{r}-0.050401 \\
(0.03621) \\
{[-1.39185]}\end{array}$ & $\begin{array}{r}-0.001466 \\
(0.08990) \\
{[-0.01630]}\end{array}$ & $\begin{array}{r}-0.039886 \\
(0.04847) \\
{[-0.82294]}\end{array}$ \\
\hline$R(-1)$ & $\begin{array}{r}-0.035488 \\
(0.27803) \\
{[-0.12764]}\end{array}$ & $\begin{array}{r}0.583482 \\
(0.97115) \\
{[0.60081]}\end{array}$ & $\begin{array}{r}-0.047829 \\
(0.20867) \\
{[-0.22920]}\end{array}$ & $\begin{array}{r}-0.044903 \\
(0.51804) \\
{[-0.08668]}\end{array}$ & $\begin{array}{r}1.039238 \\
(0.27930) \\
{[3.72091]}\end{array}$ \\
\hline$R(-2)$ & $\begin{array}{r}-0.078593 \\
(0.38304) \\
{[-0.20518]}\end{array}$ & $\begin{array}{r}-1.580649 \\
(1.33797) \\
{[-1.18138]}\end{array}$ & $\begin{array}{r}0.389580 \\
(0.28749) \\
{[1.35511]}\end{array}$ & $\begin{array}{r}0.849796 \\
(0.71371) \\
{[1.19068]}\end{array}$ & $\begin{array}{r}-0.308423 \\
(0.38479) \\
{[-0.80153]}\end{array}$ \\
\hline
\end{tabular}




\begin{tabular}{|c|c|c|c|c|c|}
\hline$R(-3)$ & $\begin{array}{r}-0.001224 \\
(0.29013) \\
{[-0.00422]}\end{array}$ & $\begin{array}{r}1.600961 \\
(1.01341) \\
{[1.57978]}\end{array}$ & $\begin{array}{r}0.575622 \\
(0.21775) \\
{[2.64349]}\end{array}$ & $\begin{array}{r}-1.621212 \\
(0.54057) \\
{[-2.99905]}\end{array}$ & $\begin{array}{r}-0.945592 \\
(0.29145) \\
{[-3.24446]}\end{array}$ \\
\hline$X R(-1)$ & $\begin{array}{r}-0.176861 \\
(0.18946) \\
{[-0.93351]}\end{array}$ & $\begin{array}{r}-0.173906 \\
(0.66178) \\
{[-0.26279]}\end{array}$ & $\begin{array}{c}0.139247 \\
(0.14220) \\
{[0.97926]}\end{array}$ & $\begin{array}{r}0.569632 \\
(0.35301) \\
{[1.61365]}\end{array}$ & $\begin{array}{r}0.119205 \\
(0.19032) \\
{[0.62633]}\end{array}$ \\
\hline$X R(-2)$ & $\begin{array}{c}0.054334 \\
(0.20502) \\
{[0.26503]}\end{array}$ & $\begin{array}{r}0.982400 \\
(0.71612) \\
{[1.37184]}\end{array}$ & $\begin{array}{r}0.074591 \\
(0.15387) \\
{[0.48476]}\end{array}$ & $\begin{array}{r}-0.322684 \\
(0.38199) \\
{[-0.84473]}\end{array}$ & $\begin{array}{r}-0.381226 \\
(0.20595) \\
{[-1.85106]}\end{array}$ \\
\hline$X R(-3)$ & $\begin{array}{r}0.017595 \\
(0.13497) \\
{[0.13037]}\end{array}$ & $\begin{array}{r}-0.197403 \\
(0.47143) \\
{[-0.41873]}\end{array}$ & $\begin{array}{r}0.137369 \\
(0.10130) \\
{[1.35609]}\end{array}$ & $\begin{array}{r}0.047209 \\
(0.25147) \\
{[0.18773]}\end{array}$ & $\begin{array}{r}0.026610 \\
(0.13558) \\
{[0.19627]}\end{array}$ \\
\hline$Y(-1)$ & $\begin{array}{r}0.237431 \\
(0.23503) \\
{[1.01022]}\end{array}$ & $\begin{array}{r}2.356010 \\
(0.82096) \\
{[2.86984]}\end{array}$ & $\begin{array}{r}-0.063190 \\
(0.17640) \\
{[-0.35822]}\end{array}$ & $\begin{array}{r}-0.535039 \\
(0.43792) \\
{[-1.22178]}\end{array}$ & $\begin{array}{r}0.409370 \\
(0.23610) \\
{[1.73388]}\end{array}$ \\
\hline $\mathrm{Y}(-2)$ & $\begin{array}{r}-0.103522 \\
(0.30269) \\
{[-0.34200]}\end{array}$ & $\begin{array}{r}-2.557144 \\
(1.05730) \\
{[-2.41856]}\end{array}$ & $\begin{array}{r}0.018346 \\
(0.22718) \\
{[0.08075]}\end{array}$ & $\begin{array}{r}1.142768 \\
(0.56399) \\
{[2.02622]}\end{array}$ & $\begin{array}{r}0.390319 \\
(0.30407) \\
{[1.28364]}\end{array}$ \\
\hline$Y(-3)$ & $\begin{array}{r}-0.001688 \\
(0.15802) \\
{[-0.01068]}\end{array}$ & $\begin{array}{r}1.416462 \\
(0.55198) \\
{[2.56615]}\end{array}$ & $\begin{array}{r}0.243388 \\
(0.11860) \\
{[2.05211]}\end{array}$ & $\begin{array}{r}-0.900841 \\
(0.29444) \\
{[-3.05952]}\end{array}$ & $\begin{array}{r}-0.699599 \\
(0.15875) \\
{[-4.40706]}\end{array}$ \\
\hline C & $\begin{array}{r}1.796884 \\
(1.74706) \\
{[1.02852]}\end{array}$ & $\begin{array}{r}5.118083 \\
(6.10247) \\
{[0.83869]}\end{array}$ & $\begin{array}{r}-0.023133 \\
(1.31124) \\
{[-0.01764]}\end{array}$ & $\begin{array}{r}4.989832 \\
(3.25520) \\
{[1.53288]}\end{array}$ & $\begin{array}{r}-4.886436 \\
(1.75502) \\
{[-2.78425]}\end{array}$ \\
\hline R-squared & 0.990984 & 0.930770 & 0.979846 & 0.846529 & 0.996698 \\
\hline Adj. R-squared & 0.983029 & 0.869685 & 0.962063 & 0.711114 & 0.993785 \\
\hline Sum sq. resids & 0.003030 & 0.036968 & 0.001707 & 0.010519 & 0.003058 \\
\hline S.E. equation & 0.013350 & 0.046633 & 0.010020 & 0.024875 & 0.013411 \\
\hline F-statistic & 124.5714 & 15.23727 & 55.09962 & 6.251360 & 342.1365 \\
\hline Log likelihood & 106.5544 & 65.27937 & 116.0241 & 86.01784 & 106.4043 \\
\hline Akaike AIC & -5.488144 & -2.986628 & -6.062068 & -4.243506 & -5.479048 \\
\hline Schwarz SC & -4.762565 & -2.261049 & -5.336488 & -3.517926 & -4.753469 \\
\hline Mean dependent & 14.94122 & 0.102758 & 0.185773 & 3.953862 & 14.67097 \\
\hline S.D. dependent & 0.102480 & 0.129179 & 0.051444 & 0.046281 & 0.170120 \\
\hline \multicolumn{2}{|c|}{ Determinant Residual Covariance } & $6.94 \mathrm{E}-19$ & & & \\
\hline \multicolumn{2}{|c|}{ Log Likelihood (d.f. adjusted) } & 455.7600 & & & \\
\hline \multicolumn{2}{|c|}{ Akaike Information Criteria } & -22.77333 & & & \\
\hline \multicolumn{2}{|c|}{$\begin{array}{l}\text { Akalke Information Criteria } \\
\text { Schwarz Criteria }\end{array}$} & -19.14543 & & & \\
\hline
\end{tabular}

tersebut dapat diambil kesimpulan bahwa tidak ditemukan hubungan kausalitas dua arah di antara kelima variabel tersebut. 


\section{Pengujian Impulse Response dari Var}

Impulse Response Function menggambarkan respon dari setiap variabel terhadap struktural inovasi variabel lainnya dalam model pada periode waktu bersamaan. Estimasi impulse response dapat dilihat pada masa sekarang dan diwaktu yang akan datang.

Berdasarkan gambar 2 dapat dilihat bahwa respon variabel $\mathrm{M}_{2}$ terhadap inflasi adalah ketika ada shock dari kenaikkan inflasi maka dampaknya terhadap permintaan uang $\mathrm{M}_{2}$ mula-mula mengalami penurunan pada kuartal ke-2 kemudian naik dan mencapai titik tertingginya pada kuartal ke-4 setelah itu turun dan stabil setelah kuartal ke 10. Walaupun kenaikannya semakin lama semakin besar sampai dengan periode kuartal ke-10 namun kenaikan tersebut tidak mencapai titik keseimbangan.
Jika dilihat pada respon permintaan uang $\mathrm{M}_{2}$ terhadap suku bunga maka ketika ada kenaikkan suku bunga maka dampaknya cukup fluktuatif (naik turun) dan mulai stabil pada kuartal ke 11 walaupun tidak mencapai titik keseimbangan. Sementara itu respon $\mathrm{M}_{2}$ terhadap variabel kurs adalah ketika ada shock kenaikan nilai tukar maka dampaknya akan mengalami penurunan permintaan uang $\mathrm{M}_{2}$ yang besarannya cukup fluktuatif dan mulai stabil setelah kuartal ke-8.

Dari gambar 2 tersebut juga dapat dilihat bahwa respon variabel permintaan uang $\mathrm{M}_{2}$ terhadap pendapatan nasional adalah apabila ada kenaikan shock dari variabel pendapatan nasional maka akan berdampak terhadap peningkatan permintaan uang $\mathrm{M}_{2}$ yang besarannya cukup fluktuatif. Pergerakan ini mulai stabil pada kuartal ke 8 .

Response to Cholesky One S.D. Innovations \pm 2 S.E.
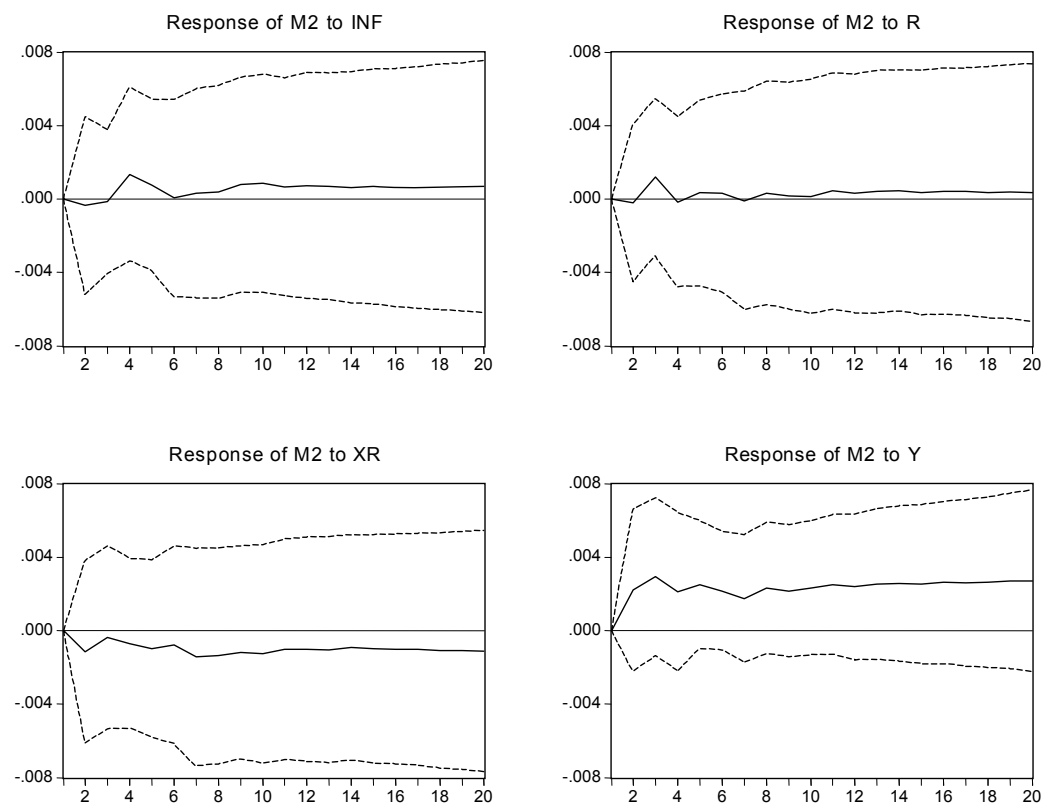

Gambar 2. Impulse Response dari VAR 


\section{Variance Decomposition dari $\mathbf{M}_{\mathbf{2}}$}

Dari hasil analisis diketahui bahwa kontribusi shock variabel inflasi terhadap permintaan uang $\mathrm{M}_{2}$ mula-mula hanya sebesar 5,12 persen pada kuartal ke-2 setelah itu mengalami kenaikan dan mencapai titik tertingginya pada kuartal ke-5 sebesar 52,26 persen setelah itu kontribusinya mengalami keadaan yang fluktuatif dan setelah kuartal ke-12 kondisinya cenderung menurun. Kontribusi shock variabel tingkat bunga terhadap permintaan uang $\mathrm{M}_{2}$ sebesar 43,73 persen, setelah itu kontribusinya selalu mengalami penurunan, sampai dengan periode kuartal ke-20 kontribusinya menjadi sebesar 15,8 persen.

Kontribusi shock variabel nilai tukar terhadap permintaan uang $\mathrm{M}_{2}$ sebesar 0,55 persen, setelah itu kontribusinya selalu mengalami kenaikan. Sampai dengan periode kuartal ke-10 kontribusinya sebesar 1,13 persen namun terus mengalami penurunan. Kontribusi shock variabel pendapatan nasional terhadap permintaan uang $\mathrm{M}_{2}$ sebesar 2,05 persen pada kuartal kedua, setelah itu kontribusinya selalu mengalami kenaikan, sampai dengan periode kuartal ke-20 kontribusinya menjadi sebesar 5,42 persen.

\section{Estimasi Model ADL ECM}

Nilai ECT yang diperoleh dari hasil estimasi dengan metode kemungkinan terbesar (maximum likelihood methods) periode 1997.1.2006.4 seperti terlihat dalam persamaan 20.

ECTt-1 $=\mathrm{M} 2_{\mathrm{t}-1}-0.992216 \mathrm{Y}_{\mathrm{t}-1}-$

$$
0.102853 \mathrm{XR}_{\mathrm{t}-1}
$$

Setelah didapatkan nilai ECT-nya selan-

Tabel 6. Variance Decomposition dari $\mathrm{M}_{2}$

\begin{tabular}{ccccccc}
\hline Period & S.E. & M2 & INF & R & XR & Y \\
\hline 1 & 0.013350 & 100.0000 & 0.000000 & 0.000000 & 0.000000 & 0.000000 \\
2 & 0.015438 & 97.31852 & 0.051243 & 0.020625 & 0.557130 & 2.052477 \\
3 & 0.018161 & 94.96562 & 0.044148 & 0.437314 & 0.444897 & 4.108023 \\
4 & 0.019645 & 93.94593 & 0.500858 & 0.380871 & 0.508195 & 4.664150 \\
5 & 0.021823 & 93.44062 & 0.522639 & 0.331059 & 0.616973 & 5.088714 \\
6 & 0.024060 & 93.67414 & 0.430552 & 0.287892 & 0.612195 & 4.995224 \\
7 & 0.025671 & 93.65795 & 0.393043 & 0.253987 & 0.849843 & 4.845173 \\
8 & 0.027307 & 93.39646 & 0.365960 & 0.237812 & 1.004539 & 4.995226 \\
9 & 0.028899 & 93.30018 & 0.398452 & 0.215920 & 1.068344 & 5.017104 \\
10 & 0.030400 & 93.11123 & 0.436917 & 0.196797 & 1.139797 & 5.115263 \\
11 & 0.032042 & 93.02633 & 0.434180 & 0.195401 & 1.128380 & 5.215709 \\
12 & 0.033581 & 93.00438 & 0.441786 & 0.185527 & 1.119366 & 5.248945 \\
13 & 0.035130 & 92.95221 & 0.441626 & 0.182093 & 1.111660 & 5.312411 \\
14 & 0.036721 & 92.95073 & 0.433587 & 0.181513 & 1.082086 & 5.352081 \\
15 & 0.038253 & 92.96421 & 0.430030 & 0.175938 & 1.065414 & 5.364405 \\
16 & 0.039796 & 92.96678 & 0.420388 & 0.173802 & 1.048806 & 5.390225 \\
17 & 0.041324 & 92.98871 & 0.412407 & 0.170359 & 1.032688 & 5.395835 \\
18 & 0.042813 & 92.99650 & 0.407306 & 0.165528 & 1.026657 & 5.404008 \\
19 & 0.044307 & 93.00097 & 0.401069 & 0.162298 & 1.019942 & 5.415724 \\
20 & 0.045776 & 93.00743 & 0.397324 & 0.158005 & 1.016614 & 5.420625 \\
\hline & & \multicolumn{2}{c}{ Cholesky Ordering: M2 INF R XRY } & & \\
\hline
\end{tabular}


jutnya dilakukan estimasi ADL ECM dengan simulasi pertama yaitu memasukkan ECT tetapi tanpa variabel kurs, sehingga didapatkan hasil seperti pada persamaan 21 .

$$
\begin{aligned}
\mathrm{DM} 2= & -0.002147 \mathrm{ECT}_{\mathrm{t}-1}+0.068736 \mathrm{DY}+ \\
& (-0.042568) \\
& 0.004333 \mathrm{DINF}-0.145937 \mathrm{DR} \\
& (0.143676)
\end{aligned}
$$

$\mathrm{R} 2=0.530476 ; \quad \mathrm{DW}=1.615692 ;$

$\mathrm{JB}(2)=2.0294$

Angka koreksi kesalahan (error correction term) atau $\mathrm{ECT}_{\mathrm{t}-1}$ memiliki koefisien yang negatif yang menunjukkan adanya penyesuaian menuju keseimbangan jangka panjang (long run equilibrium) dengan nilai t-statistik yang tidak signifikan. Koefisien ECT lebih kecil dari keseluruhan koefisien masing-masing variabel. Hal ini menunjukkan kecepatan penyesuaian menuju keseimbangan jangka panjang lebih rendah dari kecepatan penyesuaian pendapatan nasional (DY), inflasi (DINF) dan suku bunga (DR).

Tanda pada regressor sesuai dengan hipotesis dimana pendapatan nasional (LYR) memiliki tanda positif. Tingkat inflasi alamiah (rate of inflation naturally) memiliki koefisien positif yang dampaknya akan menambah tingkat keseimbangan permintaan uang $\mathrm{M}_{2}$ di Indonesia ketika terjadi tingkat inflasi yang meningkat.

Simulasi yang kedua adalah dengan menghilangkan ECT dan variabel kurs, didapatkan hasil estimasi seperti disajikan pada persamaan 22 .

$$
\begin{aligned}
\mathrm{DM} 2= & 0.067259 \mathrm{DY}+0.004331 \mathrm{DINF}+ \\
& (0.624268) \quad(1.004939) \\
& 0.145596 \mathrm{DIR} \\
& (0.145767)
\end{aligned}
$$

$$
\mathrm{R}^{2}=0.530 ; \quad \mathrm{DW}=1.61
$$

Dari hasil estimasi di atas, dapat disimpulkan bahwa ketidakseimbangan jangka pendek (short run disequilibrium) tidak berpengaruh pada angka koefisien yang diestimasi ketika kecepatan penyesuaian menuju keseimbangan jangka panjang kecil (bisa dilihat angka koefisien ECT pada simulasi 1 di atas yang sebesar -0.002). Hal ini bisa ditunjukkan koefisien pendapatan nasional berubah dari 0.068 menjadi 0.067 , koefisien inflasi tidak berubah (0.00433) dan variabel suku bunga berubah dari 0.145 menjadi 0.146 .

Simulasi yang ketiga adalah dengan memasukkan ECT dan variabel kelambanan kurs, didapatkan hasil estimasi sebagai berikut:

$$
\begin{aligned}
& \mathrm{DM} 2=-0.008258 \mathrm{ECT}+0.079827 \mathrm{DY}+ \\
& (-0.202947) \quad(0.862622) \\
& 0.218982 \mathrm{DXR}+0.012486 \mathrm{DINF} \\
& \text { (4.331162) (0.511945) } \\
& -0.015018 \mathrm{DR} \\
& \text { (0.122563) }
\end{aligned}
$$

$\mathrm{R}^{2}=0.035 ; \quad \mathrm{DW}=1.23$

Dari hasil estimasi tersebut, ditemukan bahwa nilai koefisien yang diestimasi tidak berubah banyak dari hasil estimasi mulamula. Nilai kelambanan dari variabel kurs DXR signifikan. Hal ini menunjukkan 
masyarakat akan melakukan keseimbangan portofolionya dalam mengalokasikan asetasetnya utamanya dalam bentuk aset-aset luar negeri (terutama dollar).

Dari hasil estimasi di atas diakui bahwa kemampuan nilai tukar atau kurs dalam menjelaskan variasi ketidakseimbangan jangka pendek permintaan uang tidaklah terlalu efektif karena model ECM nya sendiri tidak memberikan hasil yang signifikan. Kesimpulan ini sama dengan yang dikemukakan oleh Baba, et.al (1992) dan Morimune dan Zhao (1997). Hubungan antara nilai tukar dan jumlah uang beredar tergantung pada harapan (expectation) pemegang uang sehingga sulit untuk mempertahankan hubungan yang stabil antara nilai tukar dan permintaan uang $\mathrm{M}_{2}$.

Dalam kondisi semacam ini, masyarakat Indonesia pada periode penelitian cenderung berpendapat bahwa memegang uang bukan hanya untuk tujuan transaksi, tetapi lebih kepada tujuan untuk berjaga-jaga, bahkan tidak tertutup kemungkinan untuk motif spekulasi. Selama masa krisis ini, mata uang asing khususnya dolar menjadi salah satu alat bagi para pelaku ekonomi untuk menimbun kekayaan bahkan mampu meningkatkan nilai atau harga assetnya (kekayaan) terutama bagi para spekulan.

\section{KESIMPULAN}

Dari hasil analisis dapat ditarik tiga kesimpulan sebagai berikut:

1. Terdapat kondisi non stasionaritas terhadap data time series (runtun waktu) dalam periode penelitian sehingga menyebabkan stabilitas ekonomi makro sulit dicapai.
2. Kecepatan penyesuaian menuju keseimbangan di antara variabel-variabel permintaan uang riil, pendapatan nasional, kurs, inflasi dan suku bunga membutuhkan waktu tiga kuartal dan tidak ditemukan hubungan kausalitas dua arah di antara kelima variabel yang dipakai dalam penelitian. Sementara itu dari impulse response diketahui bahwa respon variabel $\mathrm{M}_{2}$ terhadap empat variabel lainnya sangat fluktuatif terutama ketika variabel lain mengalami shock, namun kondisi ini pada akhirnya akan kembali stabil.

3. Hubungan antara nilai tukar dan jumlah uang beredar di Indonesia selama periode pengamatan tergantung pada harapan (expectation) pemegang uang sehingga sulit untuk mempertahankan hubungan yang stabil antara nilai tukar dan permintaan uang $\mathrm{M}_{2}$. Masyarakat Indonesia cenderung berpendapat bahwa memegang uang bukan hanya untuk tujuan transaksi, tetapi lebih kepada tujuan untuk berjaga-jaga, bahkan tidak tertutup kemungkinan untuk motif spekulasi.

Dua kebijakan yang direkomendasikan antara lain pertama, otoritas moneter diharapkan mampu mengontrol keberadaan faktor-faktor yang mempengaruhi permintaan uang termasuk kurs, inflasi, suku bunga dan pendapatan nasional. Hal ini dilakukan agar pertumbuhan permintaan uang dapat dilakukan dengan stabil. Saran kedua, strategi dengan target nilai kurs layak dipertimbangkan terutama pada kondisi ketidakstabilan permintaan uang yang diakibatkan oleh adanya kurs yang sangat fluktuatif. Target nilai kurs merupakan target yang sederhana. Untuk itu keberadaan Bank Sentral dibutuhkan untuk mempertahankan nilai tukar 
yang tetap agar mata uang dari negara yang banyak melakukan perdagangan (baskets of trading partner currencies) terjaga tingkat kestabilannya.

\section{DAFTAR PUSTAKA}

Baba, Y., D.F. Hendry, dan R.M. Starr, 1992, The Demand for $\mathrm{M}_{1}$ in the USA, 19601988. Review Economic Studies. 59. 2561.

Badan Pusat Statistik. 2003. Indikator Ekonomi. www.bps.go.id

Bank Indonesia. 1997. Laporan Tahunan Bank Indonesia. www.bi.go.id

Bank Indonesia. 1999. Laporan Tahunan Bank Indonesia. www.bi.go.id

Dickey, D.P., dan W.A., Fuller. 1981. Likelihood Ratio Statistics for Autoregressive Time Series with a Unit Root. Econometrica (Journal). 49. 1057 1072.

Domowitz, I, dan Elbadawi. 1987. An Error Correction Approach to Money Demand: The Case of Sudan. Journal of Development Economics. 25.257-275.

Dutton, D.S dan Gramm, W.P. 1973. Transaction Cost, The Wage Rate dan The Demand for Money. American Economic Review. No. 63, 652-665
Greene, W.H. 2000. Econometric Analysis. Fourth Edition. Prentice Hall

Gujarati, D., 2003. Basic Econometric. Fifth Edition. New Jersey: McGraw-Hill, Inc.

Handoyo, R.D. (2002). Permintaan Uang $M_{1}$ Asean-4, Singapura, Thailand, Malaysia dan Indonesia, 1980.1-1999.4, Estimasi Data Non Stasioner. Tesis. Universitas Gadjah Mada, tidak dipublikasikan.

Hendry, D., dan Ericson N. 1991. Econometric Analysis U.K. Money Demand in Monetary Trends in the United States and the United Kingdom. The American Economic Review. 81. 1-80.

Insukindro. 1991. Regresi Linier Lancung dalam Analisis Ekonomi: Suatu tinjauan dengan Studi Kasus Indonesia. Jurnal Ekonomi dan Bisnis Indonesia. 18-23.

Insukindro. 1998. Sindrum $\mathrm{R}^{2}$ dalam Analisis Regresi Linier Runtun Waktu. Jurnal Ekonomi dan Bisnis Indonesia. 7, 1-17

Morimune, K dan Zhao,G.Q. 1997. Non Stationary Estimation of the Japanese Money Demand Function. Journal of Economic Research. 2.1-28

Wickens, M.R., dan Brusch T.S.1988. The Dynamics Specification, The Long-run and Estimation of Transformed Regression Models. Economic Journal. 98. (Suplemen). 189-205. 